\title{
HUBUNGAN TIPE KEPRIBADIAN BERDASARKAN TEMPERAMEN DENGAN TINGKAT MOTIVASI BELAJAR
}

\author{
Pringga Adityawan \\ pringgadity@gmail.com
}

STIKES Widyagama Husada

\begin{abstract}
Personality Type Based on Temperament in each individual can affect the way they make a perception and act. Motivation can be the factor in each individual which can affect the quality of students in education process. The objective of this research is to identify positive relationship between Personality Type Based on Temperament with Motivation Level of Study of Students JIK 2007 A. The researcher used correlative researchmethodamong variable with crossectional approach. Researcher used all population in JIK 2007 A which it is consist of 60 students with Total Sampling Method.Based on Fisher analytical method, the result showed $p=0.033(p<0.05)$, coefficient contingency 0,344 and $R$ square 0,013. It means there is a relationship between personality types based on Temperament with Motivation Level of Study. Based on the result of this research, for nurse in education department, hoped they begin to include type of personality as one of aspect in education process. And For furthermore study, hoped researcher can develop a better motivation questioner related to type of personality.
\end{abstract}

Keywords: Personality Type, Study Motivation Level 


\begin{abstract}
ABSTRAK
Tipe Kepribadian Berdasar Temperamen suatu individu sangatlah mempengaruhi kecenderungan suatu individu tersebut dalam berperilaku dan mempersepsikan sesuatu. Motivasi menjadi factor pada diri individu yang mempengaruhi berhasil tidaknya mahasiswa dalam proses belajar. Penelitian ini bertujuan untuk mengetahui ada tidaknya hubungan antara Tipe Kepribadian Berdasar Temperamen dengan Tingkat Motivasi Belajar Mahasiswa JIK 2007 A. Desain penelitian yang digunakan adalah desain crosssectional. Sampel dipilih dengan menggunakan teknik total sampling. Jumlah sampel yang digunakan adalah 60 mahasiswa Jurusan Keperawatan Universitas Brawijaya angkatan 2007 program A. Hasil penelitian menunjukkan adanya hubungan antara Tipe Kepribadian Berdasar Temperamen dengan Tingkat Motivasi Belajar, sifatnya positif namun lemah. Berdasarkan uji statistic Fisher diperoleh $p=0.033(p<0.05)$, koefisien kontingensi 0,344 dan $R$ square sebesar 0,013. Kesimpulan dari penelitian ini adalah adanya hubungan antara Tipe Kepribadian Berdasar Temperamen dengan Tingkat Motivasi Belajar. Berdasarkan hasil penelitian, bagi para perawat pengajar diharapkan mulai mempertimbangkan aspek kepribadian berdasarkan temperamen dalam menjalankan proses belajar mengajar. Bagi peneliti selanjutnya, diharapkan lebih dapat mengembangkan instrument pengukur motivasi belajar yang berhubungan dengan tipe kepribadian.
\end{abstract}

Kata kunci: Tipe Kepribadian, Tingkat Motivasi Belajar

\section{PENDAHULUAN}

Pendidikan merupakan hal yang sangat penting dalam mencetak sumber daya manusia yang berkualitas. Hal tersebut juga mencakup dalam dunia keperawatan. Karena melalui sistem pendidikan yang baiklah tenaga keperawatan profesional akan tercipta. Sistem pendidikan yang baik pastilah memiliki cara pembelajaran yang baik pula, sebab kegiatan belajar dan pembelajaran adalah inti kegiatan dalam pendidikan (Nasser, 2000). Cara pembelajaran yang baik tidak hanya mempertimbangkan aspek kemampuan pengajar dalam mengajar namun juga kemampuan pengajar dalam mengidentifikasi faktor-faktor yang mempengaruhi motivasi siswa dalam belajar. Sebab dalam kegiatan belajar dan pembelajaran, motivasi memiliki peranan tersendiri.
Motivasi menjadi faktor pada diri individu yang mempengaruhi berhasil tidaknya mahasiswa dalam proses belajar dan pembelajaran (Slameto, 2003) di perkuliahan. Salah satu prinsip dalam belajar dan pembelajaran di perkuliahan adalah mahasiswa harus secara aktif mengambil peranan dalam kegiatan belajar dan pembelajaran. Berbeda dengan siswa, mahasiswa dituntut untuk lebih mandiri dalam proses belajar dan pembelajarannya. Hal ini disebabkan mahasiswa sudah tergolong dalam fase dewasa muda yang dianggap telah mampu mandiri dan berkomitmen terhadap diri sendiri dalam kehidupannya (Alwisol, 2008). Hal itu termasuk dalam urusan belajar dan perkuliahan. Agar hal tersebut dapat terlaksana dibutuhkan adanya kemauan dan dorongan untuk terlibat dalam keseluruhan kegiatan belajar dan pembelajaran. Di sini 
terlihat pentingnya peranan motivasi (Karlina, 2010).

Motivasi setiap individu selcara tidak langsung selalu erat kaitannya dengan kepribadian seseorang. Hal ini disebabkan kepribadian merupakan suatu totalitas dari disposisi atau kecenderungan suatu individu yang terorganisir, artinya kepribadian yang berbeda akan menghasilkan kecenderungan berpikir dan berperilaku yang berbeda. Kecenderungan - kecenderungan ini akhirnya berdampak pada dimensi psikologis individu seperti perbedaan persepsi terhadap suatu kebutuhan, motif, harapan dan insentif (nonmateriil).

Faktor psikologis tersebuti merupakan unsur utama dari suatu motivasi. Menurut Atkinson, semakin kuat persepsi akan kebutuhan, motif, harapan dan insentif (non-materiil), maka semakin besar pula motivasi yang ditimbulkan. Motivasi yang ditimbulkan akibat factor internal tersebut kemudian akan menyebabkan individu melakukan suatu gerak dan membentuk perilaku. Berdasarkan literatur-literatur, dapat diduga bahwa tipe kepribadian tertentu memiliki tingkat motivasi yang berbeda dibanding tipe kepribadian lainnya.Hal ini disebabkan tipe kepribadian seorang individu melibatkan faktor psikologis yang kemudian mempengaruhi perilaku individu tersebut (Kartono, 2005).

Menurut Hypocrates dan Galenus terdapat 4 jenis tipe kepribadian manusia yang digolongkan berdasarkan dominasi jenis cairan dalam tubuhnya (Suryabrata, 2008). Tipe-tipe kepribadian itu memiliki kecenderungan - kecenderungan berperilaku yang berbeda (Kartono, 2005). Dalam psikologi kesehatan juga dikatakan kepribadian merupakan hal yang penting yang ada dalam setiap individu, dan dalam satu individu dengan individu lain pasti berbeda, karena kemampuan setiap individu mempunyai batas tertentu dalam melakukan tindakan yang ditentukan oleh kerpibadian seseorang (Suharto, 2009). Hal ini lalu memunculkan dugaan bahwa tingkat motivasi setiap individu juga berbeda - beda sebagaimana perbedaan tipe kepribadiannya.

Berdasar penelitian sebelumnya yang dilakukan oleh Gatiningsih (2010) pada Mahasiswa Jurusan Keperawatan Transfer Universitas Muhammadiyah Surakarta, perihal hubungan tipe kepribadian dengan motivasi, secara statistik, didapatkan hasil bahwa secara statistik ada korelasi positif yang cukup kuat antara tipe kepribadian dengan motivasi. Penelitian tersebut mengatakan bahwa mayoritas mahasiswa yang memiliki motivasi tinggi adalah berasal dari golongan ekstrovert, yaitu sebesar 61,3 $\%$. Sedangkan sisanya sebesar $38,7 \%$ berasal dari pribadi introvert. Hasil penelitian ini mendukung hipotesis peneliti dalam penelitian tentang hubungan tipe kepribadian berdasar temperamen terhadap tingkat motivasi belajar mahasiswa Keperawatan 2007 A Universitas Brawijaya. Penelitian ini didasarkan pada analisis resiko timbulnya masalah akibat panjangnya masa studi mahasiswa keperawatan di Universitas Brawijaya. Dimana masa studinya meliputi tahap akademik selama empat tahun dan satu tahun tahap profesi (Siakad PSIK FKUB Malang, 2008).

Hasil studi pendahuluan mahasiswa Jurusan Ilmu Keperawatan Fakultas Kedokteran Universitas Brawijaya angkatan 2007 program A (yang selanjutnya disebutkan sebagai JIK $2007 \quad$ A) memperlihatkan bahwa dari 16 orang yang di survey random dengan menggunakan questioner dan wawancara seputar motivasi kepribadian. Ditemukan, terdapat perbedaan persepsi dan penyikapan terhadap aktivitas perkuliahan.

Pada study pendahuluan ini, tingkat motivasi diukur secara sederhana dengan mempertimbangkan aspek keaktifan mahasiswa dalam mengikuti kegiatan perkuliahan. Hal tersebut diwakili oleh 
banyak sedikitnya frekuensi mereka meminta teman untuk mengisikan daftar kehadiran. Semakin sering mereka meminta temannya untuk mengisi daftar kehadiran, dapat disimpulkan bahwa semakin lemah tingkat motivasi mereka untuk kuliah. Aspek lainnya yang dipertimbangkan adalah kebiasaan mahasiswa dalam belajar yang diwakili oleh pertanyaan seputar kebiasaan belajarnya sehari-hari.

Dua aspek tersebut dipakai sebagai tolak ukur sederhana study pendahuluan tingkat motivasi belajar dengan mempertimbangan pendapat Ratumanan (2004), yang mengatakan bahwa seseorang yang termotivasi belajar akan memperlihakan beberapa perilaku khas, diantaranya adalah memiliki orientasi masa depan dan menganggap perkuliahan sebagai jembatan pencapaian cita-cita. Sehingga kehadiran dalam perkuliahan merupakan sesuatu yang penting. Selain itu Ratumanan (2004) juga mengatakan bahwa mahasiswa yang termotivasi akan menyempatkan waktu untuk belajar di setiap harinya.

Dari fenomena yang ada, dapat diduga bahwa tingkat motivasi belajar mahasiswa JIK 2007 A sangat bervariasi. Hal ini berkaitan dengan tipe kepribadian masing - masing mahasiswa. Pemahaman akan tipetipe kepribadian ini dapat mengantarkan para pengajar atau civitas akademika lainnya untuk lebih memahami kecenderungan sikap dan perilaku mahasiswa terdidik terkait motivasi belajarnya. Pemahaman akan tipe kepribadian ini juga dapat membantu para pendidik untuk dapat memprediksikan perjalanan perkuliahan mahasiswa ke depan sehingga para pendidik dapat mempersiapkan system yang lebih baik untuk memaksimalkan seluruh potensi mahasiswa dengan tipe kepribadian yang berbeda-beda.

\section{METODE PENELITIAN}

Penelitian ini menggunakan desain penelitian cross sectional. Populasi dalam penelitian ini adalah seluruh mahasiswa jurusan keperawatan program A angkatan 2007 Universitas Brawijaya sebanyak 60 mahasiswa. Cara pengambilan sampel dalam penelitian ini menggunakan teknik Total sampling. Penelitian dilakukan di Jurusan Keperawatan Fakultas Kedokteran Universitas Brawijaya Malang selama bulan Desember 2010.

Sebelum dilakukan penelitian, dilakukan proses persiapan diantaranya pembuatan dan uji validitas dan reliabilitas instrumen penelitian berupa kuesioner. Menggabungkan data penelitian yang diperoleh (berupa data tipe kerpibadian berdasarkan temperamen dengan tingkat motivasi belajar populasi JIK 2007 A) ke dalam tingkat tinggi, sedang dan rendah untuk motivasi dan sanguinis, koleris, melankolis, phlegmatic pada tipe kepribadian, kemudian membuat tabulasi silang dan dianalisis secara statistik menggunakan fasilitas SPSS 16 for Windows dengan derajat kepercayaan 95\% $(p<0,05)$ dengan menggunakan uji statistik Fisher. 


\section{HASIL PENELITIAN DAN ANALISIS}

Tabel 1. Tabulasi Silang Tipe Kepribadian Dominan dengan Tingkat Motivasi

\begin{tabular}{|c|c|c|c|c|c|}
\hline & & & tingk & & \\
\hline & & & Rendah & Sedang & Total \\
\hline Tipe & Sanguinis & Count & 8 & 4 & 12 \\
\hline & & Expected Count & 7.2 & 4.8 & 12.0 \\
\hline & Koleris & Count & 2 & 8 & 10 \\
\hline & & Expected Count & 6.0 & 4.0 & 10.0 \\
\hline & Melankolis & Count & 14 & 6 & 20 \\
\hline & & Expected Count & 12.0 & 8.0 & 20.0 \\
\hline & Phlegmatis & Count & 12 & 6 & 18 \\
\hline & & Expected Count & 10.8 & 7.2 & 18.0 \\
\hline Total & & Count & 36 & 24 & 60 \\
\hline & & Expected Count & 36.0 & 24.0 & 60.0 \\
\hline
\end{tabular}

Sumber: Data Primer

Hasil tabulasi silang (tabel 5.5.1) menunjukkan mahasiswa koleris memiliki prosentasi yang tinggi pada tingkat motivasi sedang disbanding tipe kepribadian yang lain. Temuan ini didukung hasil test Fisher yang menunjukkan terdapat hubungan signifikan $(\mathrm{p}=0,033,<0,05)$ antara Tipe kepribadian berdasarkan temperamen dengan tingkat motivasi. Dan koeficient kontingensi sebesar 0,344 .

\section{PEMBAHASAN}

Berdasarkan hasil pengujian menggunakan uji Fisher dapat disimpulkan bahwa ada hubungan yang signifikan antara tipe kepribadian dengan tingkat motivasinya. Ditunjukkan dengan nilai signifikansi 0,033 ( $p=0,045$ atau $p<0,05)$. Dengan Koefisien Kontingensi sebesar 0,344 dan koefisien determinan ( $\mathrm{R}$ square) pada analisis regresi sebesar 0,013. Artinya terdapat hubungan antara variable tipe kepribadian dengan variable tingkat motivasi (nilai test Fisher $\mathrm{p}<0,05$ ), namun kekuatannya lemah karena nilai koefisien kontengensinya $<0,5$ (Wahana Statistika, 2009). $R$ square sebesar 0,013 menunjukkan bahwa variable tipe kepribadian berdasarkan temperamen dapat mempengaruhi $1,3 \%$ tingkat motivasi belajar mahasiswa JIK 2007 A, sedangkan sisanya sebesar $98,7 \%$ dipengaruhi oleh variable lain yang tidak diteliti dalam penelitian.

Secara teori, hal ini bisa terjadi karena adanya ikatan antara tipe kepribadian dengan tingkat motivasi. Hal ini disebabkan kepribadian sendiri terdiri atas unsur temperamen yang secara langsung mempengaruhi kejiwaan suatu individu. Hal tersebut sesuai definisi kepribadian menurut Morton Prince dimana kepribadian merupakan total dari semua disposisi pembawaan, Impuls - impuls, kecendrungan - kecendrungan, selera-selera, nafsu-nafsu, insting-insting individual, disposisi-disposisi dan tendensi-tendensi yang diperoleh melalui pengalaman (Kartono, 2005).

Sederhananya factor tipe kepribadian mempengaruhi cara pandang (persepsi) dan perilaku suatu individu, termasuk kuat lemahnya intensitas suatu perilaku yang seringkali diidentikkan dengan konsep motivasi. Hal ini juga didukung konsep yang menyatakan bahwa Tipe Kepribadian diduga ikut mempengaruhi motivasi belajar, 
suatu individu dikarenakan kepribadian tersusun atas disposisi (kecenderungankecenderungan) yang berbeda antara individu yang satu dengan lainnya. Perbedaan disposisi (kecenderungan kecenderungan) tersebut diduga ikut mempengaruhi dimensi psikologis (bagian psikofisik) penyebab munculnya motivasi suatu individu. Seperti persepsi kebutuhan, motif, ekspektasi dan insentif non materiil.

Sedangkan tabulasi silang antara tingkat motivasi belajar dan tipe kepribadian dominan mahasiswa JIK 2007 A menunjukkan bahwa Dari total 24 mahasiswa bermotivasi belajar tinggi, sebanyak 33,3\%nya adalah mahasiswa koleris. $25 \%$ nya adalah mahasiswa phlegmatic, 25\% lainnya adalah mahasiswa sanguinis dan $16,7 \%$ sisanya adalah mahasiswa sanguinis. Sedangkan dalam wilayah tingkat motivasi belajar rendah didapatkan hasil bahwa sebesar 38,9 \% mahasiswa bertingkat motivasi belajar rendah didominasi oleh mahasiswa dengan tipe dominan melankolis, 33,3\% didominasi oleh mahasiswa phlegmastis, 22,2 \% didominasi oleh mahasiswa bertipe kepribadian dominan sanguinis dan 0,6\% didominasi oleh mahasiswa bertipe kepribadian dominan koleris. Sehingga dapat disimpulkan terdapat variasi tingkat motivasi belajar sesuai dengan tipe kepribadian mahasiswa tersebut.

Selain itu data perihall kecenderungan suatu tipe kepribadian terhadap tinggi rendahnya tingkat motivasi belajar juga mengatakan bahwa mahasiswa dengan tipe kepribadian Koleris memiliki tingkat motivasi belajar yang cenderung lebih tinggi dibandingkan tipe kepribadian lainnya. Sebanyak $80 \%$ dari total $100 \%$ mahasiswa bertipe koleris memiliki motivasi tinggi.Sedangkan mahasiswa dengan tipe dominan Melankolis hanya 30 \%nya saja yang memiliki tingkat motivasi tinggi.Begitu pula dengan mahasiswa bertipe phlegmatic dan sanguinis. Mahasiswa dengan tipe dominan phlegmatic dan dominan sanguinis hanya 33,3\% saja yang memiliki motivasi tinggi, sedangkan sisanya sebanyak $77 \%$ berada di wilayah motivasi rendah.

Hal ini mungkin dapat dikarenakan kecederungan sifat koleris yang tidak biasa dengan keadaan stagnan dan terus menerus bergerak untuk merubah segala hal yang dianggapnya kurang tepat, selain itu tipe dominan koleris juga memiliki kemauan yang sangat kuat didukung oleh ketegasannya dalam bertindak dan mengambil keputusan, mereka juga cenderung mampu mengerjakan apa saja. Mahasiswa dengan dominan koleris juga memiliki cara kerja yang selalu berorientasi pada tujuan dan kemanfaatan.

Selain itu juga mampu mengorganisir dengan sangat efektif dan efisien. Orientasinya yang kuat terhadap tujuan membuatnya senantiasa berkembang karena tantangan-tantangan yang ada. Kecenderungan sifat-sifat dominan koleris yang positif diatas bisa jadi menajdi salah satu alasan mengapa tingkat motivasi mahasiswa dengan dominan koleris terlihat lebih tinggi dibandingkan tipe kepribadian dominan lainnya (Litteur, 1996).

Sedangkan fenomena adanya mahasiswa dominan koleris yang memiliki motivasi rendah bisa dikarenakan mahasiswa tersebut tergolong mahasiswa bertipe dominan koleris yang dangkal sehingga kecenderungan sifatnya masih lebih banyak dipengaruhi oleh kecenderungan sifat tipe kepribadian lainnya. Hal ini sesuai teori Litteur (1996) yang mengatakan bahwa meskipun seorang individu sama-sama memiliki kecendrungan berkepribadian dominan Koleris, terdapat perbedaan pada kedalaman atau intensitasnya. Mereka yang terpengaruh sangat kuat baik dari segi kecenderungan aspek kekuatan maupun aspek kelemahan 
sifat koleris dikatakan sebagai kooleris mendalam.

Sedangkan individu yang terpengaruh hanya sebagian aspek positif atau sebagian aspek negatifnya, disebut sebagai koleris yang dangkal. Seorang koleris dominan yang mendalam akan merasakan hampir semua sifat yang dimiliki oleh karakter koleris, sedangkan seorang koleris dominan yang dangkal hanya akan merasakan sebagian saja dari semua sifat yang dimiliki oleh karakter koleris, namun seorang koleris dangkal memiliki campuran sifat-sifat karakter tipe kepribadian lain baik kebaikan maupun keburukannya.

Adapun fenomena banyaknya mahasiswa bertipe dominan melankolis dan phlegmatic yang menempati wilayah mahasiswa dengan tingkat motivasi rendah mungkin disebabkan kecenderungan sifat masing-masing tipe kepribadian dominannya.Seperti kecenderungan melankolis yang mudah tertekan, mudah stress, mudah depresi dan mudah sekali sakit hati. Mereka juga memiliki kecederungan bersikap pesimis, citra dirinya pun rendah.

Selain itu mereka juga cenderung menunda-nunda sesuatu, sikapnya yang perfectionist atau serba sempurna menuntutnya untuk selalu menjadi yang nomor satu. Di sisi lain kecenderungan perfectionist tadi tidak diimbangi persepsi pandang dan semangat yang positif optimistis karena, sebagaimana disebutkan, mereka memiliki kecenderungan pesimis dan mudah depresi (Litteur, 1996).

Mental emosional seperti inii sedikit banyak mungkin akan mempengaruhi semangatnya dalam belajar. Adapun munculnya pribadi-pribadi dominan melankolis yang memiliki tingkat motivasi tinggi dan cukup, bisa dikarenakan factor kedalaman pribadi melankolisnya. Sebab, melankolis yang mendalam akan memliki sebagian besar sikap-sikap positif seorang melankolis seperti kemampuan analitisnya yang tinggi. Kepandaiannya dalam merencanakan sesuatu secara detail, tertib, rapi, teratur, terorganisasi dan teliti.Mereka juga cenderung jenius dan kreatif serta memiliki visi juga tujuan jangka panjang yang sangat jelas ke depannya. Sifat-sifat positif ini tentunya akan menunjang kegiatan belajar dan meningkatkan motivasi belajarnya.Bisa juga disebabkan lingkungan yang cenderung memotivasinya untuk belajar. Atau juga factor lain yang tidak diteliti.

Sedangkan kecenderungan sifat dominan phlegmatic yang diduga menjadi sebab rendahnya motivasi belajar antara lain antusiasme mereka yang rendah, semangat mereka yang rendah, sikapnya yang statis dan stagnan. Kebiasaan mereka yang cenderung nyaman pada kondisi comfort zone, malas dan suka menunda-nunda mengerjakan sesuatu.

Selain itu mereka juga tidak bergerak jika tidak ada tekanan atau penggerak. Kecenderungan-kecenderungan seperti ini bisa jadi merupakan penyebab lemahnya motivasi belajar mereka.Sedangkan adanya mahasiswa dominan plhegmatis yang memiliki tingkat motivasi cukup, sebagaimana tipe kepribadian lainnya, mungkin disebabkan tingkat kedalaman pribadi dominannya. Phlegmatis yang mendalam akan memiliki sebagian besar sifat positif seorang phlegmatic seperti sabar, tenang, tidak mudah tertekan karena kegiatan yang sifatnya monoton, emosinya stabi. Sikap positif ini mungkin menjadi salah satu sebab pribadi tersebut tetap memnganggap belajar sebai sesuatu yang berarti sehingga membangkitkan minat dan memicu motivasinya. Atau disebabkan sifat resesifnya merupakan sifat yang memiliki kecenderungan yang mengantarkan pada peningkatan motivasi belajar, atau juga disebabkan pengaruh teman sebaya yang selalu termotivasi untuk belajar, atau 
dikarenakan factor-faktor alasan individual yang tidak diteliti.

Fenomena mahasiswa Dominan sanguinis yang cenderung memiliki motivasi belajar rendah bisa disebabkan oleh besarnya prosentase mahasiswa dominan sanguinis dangkal dibandingkan dengan prosentase mahasiswa dominan sanguinis dalam. Sebab merujuk pada pendapat Litteur (1996) bahwa pribadi sanguinis pada dasarnya memiliki kecenderungan positif seperti antusiasme dan rasa ingin tahunya yang tinggi, kesukaanya mengambil tanggung jawab secara sukarela, pemikirannya yang kreatif, spontan dan inovatif, sehingga seharusnya mahasiswa dominan sanguinis memiliki tingkat motivasi yang tinggi sebagaimana mahasiswa dominan koleris.

Banyaknya mahasiswa dominan sanguinis dangkal memunculkan dugaan bahwa mayoritas mahasiswa dominan sanguinis hanya memiliki sebagian kecil dari sifat-sifat positif seorang sanguinis saja, sebaliknya mahasiswa tersebut memiliki sifat-sifat negative seorang sanguinis lebih banyak seperti cenderung mudah lupa, baik terhadap barang-barangnya, nama maupun segala sesuatu yang akan dia kerjakan. Tidak terorganisir, berantakan dan tidak teratur. Sifatnya mudah sekali bosan selain itu sangunis dominan juga memiliki keburukan seperti terlalu suka bermain, bercanda dan bersenang-senang saja.

Ditambah sifat-sifat negative tipe kepribadian lain yang menjadi resesifnya. Rendahnya motivasi mahasiswa dominan sanguinis ini mungkin juga dipengaruhi oleh lingkungan pergaulannya yang cenderung tidak menyukai pelajaran yang sedang ditekuninya, situasi belajar yang monoton dan membosankan atau pun factor-faktor eksternal lainnya.

\section{KESIMPULAN}

Tipe Kepribadian berdasarkan temperamen yang terdapat di JIK 2007 A berturut-turutdari yang paling dominan adalah tipe kepribadian dominan Melankolis, tipe kepribadian dominan Phlegmatis, tipe kepribadian dominan Sanguinis dan tipe kepribadian koleris.

Rata-rata tingkat motivasi belajar mahasiswa JIK 2007 A berdasarkan aspek orientasi, perhatian/minat serta ketekunan/keuletan adalah rendah.

Ada hubunganpositif yang signifikan dengan kekuatan lemah antara Tipe Kepribadian berdasarkan temperamen dengan tingkat motivasi belajar JIK 2007 A.

\section{SARAN}

Bagi para mahasiswa agar mulai memahami tipe kepribadian berdasarkan temperamennya masing-masing sehingga dengan begitu diharapkan mahasiswa dapat memaksimalkan potensi intelektual dan memperbaiki mental gaya belajarnya sesuai dengan jenis kepribadiannya masing-masing

Bagi para perawat pengajar agar mulai mempertimbangkan factor kepribadian sebagai salah satua spek dalam menentukan strategi pengajaran. Sehingga tercipta iklim belajar mengajar yang kondusif, saling pengertian dan efektif efisien.

Bagi para peneliti untuk penelitian selanjutnya sebaiknya lebih terfokus dan lebih mendalam dalam mengkaji factorfaktor yang mempengaruhi motivasi maupun kepribadian serta mampu mengembangkan instrument motivasi yang berhubungan dengan type kepribadian. 


\section{DAFTAR PUSTAKA}

Alwisol. 2008. Psikologi Kepribadian. Malang : Universitas Muhammadiyah Malang Press.

Dariyo, Agoes. 2003. Psikologi Perkembangan Dewasa Muda. Jakarta: PT.Gramedia Widiasarana Indonesia

Dimyati, Mudjiono. 2009. Belajardan Pembelajaran, PT Rineka Cipta, Jakarta.

Feist, J. \& Feist, G. J. (2006). Theories of personality.(Ed. Ke-6). New York: McGraw-Hill Inc.

Hamalik, Oemar. 2001. Proses Belajar Mengajar, Bumi Aksara, Jakarta.

Hidayat, A. Aziz Alimul. 2009. Metode Penelitian KeperawatandanTeknik Analisis Data, Salemba Medika, Jakarta.

Hidayat, Hadi. 2009. Hubungan Antara Minat Kuliah Dengan Indeks Prestasi Tahun Pertama (Studi Pada Mahasiswa Jurusan Keperawatan Program A Angkatan Tahun 2007 Universitas Brawijaya). Skripsi. Tidak diterbitkan. Fakultas Kedokteran Universitas Brawijaya, Malang.

Hjelle, L.A., \& Ziegler, D.J. (1992).Personality theories. Singapore: McGraw Hill Book.

Kandau. 1991. Psikologi Umum. Jakarta : PT.Gramedia Pustaka Utama

Karlina, Fitria. 2010. Pengaruh Penggunaan Metode Student Teams-Achievement Divisions Terhadap Peningkatan Motivasi Belajar Mahasiswa Jurusan Keperawatan Universitas Brawijaya Pada Mata Kuliah Pediatric Nursing I. Skripsi. Tidak diterbitkan. Fakultas Kedokteran Universitas Brawijaya, Malang.

Linzey\& Hall.1993. Theories of personality. (4th ed). New York: John Wiley \& Sons.

Litteur, Florence. 1996. Personality Plus. Jakarta : PT Bina Rupa Aksara.
Sardiman, A.M. 2001. Interaksi dan Motivasi Belajar Mengajar. PT Raja GrafindoPersada. Jakarta.

Slameto. 2003. Belajar dan Faktor-faktor yang Mempengaruhinya. PT. Rineka Cipta.Jakarta.

Suryabrata, Sumardi. 2008. Psikologi Kepribadian. Jakarta : PT Raja Grafindo Persada. 